JOSAR, Vol. 1 No. 2 September, 2018; p-ISSN: 2502-8251; e-ISSN: 2503-1155

Copyrights@ Balitar Islamic University, Blitar-Indonesia https://ejournal.unisbablitar.ac.id/index.php/josar

\title{
FEASIBILITY OF LOCAL WISDOM BASED BOOKLET TEACHING MATERIALS IN MALIRAN FOREST ON BIODIVERSITY MATERIAL FOR CLASS X STUDENTS
}

\author{
Eka Apriliatul Qoidah ${ }^{1)}$, Dian Puspita Anggraini ${ }^{2)}$, Maratus Sholihah ${ }^{3)}$ \\ ${ }^{1,2}$ Islamic University of Balitar; Jl. Majapahit No.04, Telp. (0342) 813145 \\ ${ }^{3}$ Biology education, FKIP Islamic University of Balitar, Blitar \\ e-mail: ${ }^{* 1}$ eckaaprilya17@gmail.com
}

\begin{abstract}
The study aims to determine the feasibility of local wisdom based booklet teaching materials in Maliran forest on biodiversity material for class $X$ students. The type of research used in study is research and development research. The development model used is the Thiagarajan, dkk. (1974) which is limited to develop stage. The booklet is validated by a team of experts including material experts, media expert, and linguistic.. The results of the validation by the expert team get an average percentage of $75,3 \%$ with a decent category. The readability test results by class $X I$ students get a percentage of $78 \%$ with a decent category. Based on the result of the validation that has been obtained, it shows that the local wisdom-based booklet teaching material in Maliran forest is worthy of being in biodiversity material for class $X$ students.
\end{abstract}

\section{Keyword: Research development, Booklet, Biodiversity}

\section{INTRODUCTION}

Maliran Forest is one of the forests that has local wisdom in the form of biodiversity, especially diversity in plants. Maliran Forest is in the Ponggok sub-district of Blitar district with an area of $\pm 882.1 \mathrm{Ha}$. The diversity of plants in the Maliran forest has not been used as a learning resource. This diversity, if used as a learning resource, can provide adequate insight for both educators and students and can increase student's enthusiasm and interest in biodiversity material, so that it can ultimately influence student learning outcomes. Based on interviews with $X$ grade teachers in SMA / MA in Blitar and Tulungagung districts, it was revealed that learning of biodiversity, especially the diversity of plants in the Maliran forest, had not been used as a learning resource.

Based on the statement above, one form of packaging object of plant diversity in Maliran forest so that it becomes an interesting teaching material, can be used in learning and can increase interest and facilitate 
JOSAR, Vol. 1 No. 2 September, 2018; p-ISSN: 2502-8251; e-ISSN: 2503-1155

Copyrights@ Balitar Islamic University, Blitar-Indonesia https://ejournal.unisbablitar.ac.id/index.php/josar

students in learning biodiversity material namely booklet teaching materials. Booklet is a publication that is not as thick as a textbook in general and has a page no more than 48 pages outside the cover count. Booklets are small books measuring $14.8 \times 21 \mathrm{~cm}$. Booklets as a learning resource can be used to attract students' interest and attention because of their simple form, containing important information accompanied by many colors and images displayed (Imtiha et al., 2014).

Similar research on local wisdom-based learning devices was also put forward by Mannan, et al. (2015) at the elementary school level. In this study shows that local wisdom-based learning devices are feasible to use. The results of the feasibility were obtained after being validated by experts and tested in class to determine the character development of students.

Similar research on booklet feasibility was carried out by Indasari (2016) by developing Bio Booklet on different material namely Echinodermata material for class $X$ high school students. The results of the development show that the Bio Booklet is worthy of being used as a source of independent learning. The feasibility of the Bio Booklet was assessed by material experts, media experts, peer reviewers, biology teachers, and student responses. The same thing that was suggested by mtiha, et al. (2014) showed that the booklet was effective and feasible to be used as a source of learning in environmental pollution material in high school. The results of the booklet feasibility assessment were obtained from material experts, media experts, and the results of student responses.

Based on the background above and supported by the results of previous studies, researchers were interested in examining plant species in the Maliran forest which could be used as learning resources. This study aims to determine the feasibility of local wisdom-based booklet teaching materials in the Maliran forest on biodiversity material. 
JOSAR, Vol. 1 No. 2 September, 2018; p-ISSN: 2502-8251; e-ISSN: 2503-1155

Copyrights@ Balitar Islamic University, Blitar-Indonesia https://ejournal.unisbablitar.ac.id/index.php/josar

\section{RESEARC METHODS}

The feasibility study of local wisdom-based booklet teaching materials in the Maliran forest for class $\mathrm{X}$ student used quantitative and qualitative approaches. Quantitative research in the form of expert team assessment scores. Qualitative research in the form of input and advice from the expert team (validator). The type of research used is research and development with the development model 4D thiagarajan (1974) which consists of defining, designing, developing without doing the disseminate stage.

The procedure of the 4D development model research starts from the stage of defining, designing, developing. Define phase aims to determine and define the requirements needed in learning by doing the front end analysis, student analysis, task analysis, and concept analysis. The design phase aims to design booklet teaching materials that will be used in the learning process by compiling tests, compiling media, and initial design. The stage of development is carried out to produce a product that has been revised based on suggestions and input from the validator.

The instruments used in this study were expert validation questionnaire and readability questionnaire. Expert validation questionnaires are filled by material experts, media experts, linguists, and readability questionnaire sheets. The data analysis technique used to measure the questionnaire is using a Likert scale with a rating scale can be seen in Table 1.

Table 1 Validator Rating Scale

\begin{tabular}{clc}
\hline No. & \multicolumn{1}{c}{ statement } & Score \\
\hline 1. & Strongly agree (SS) & 5 \\
2. & Agree (S) & 4 \\
3. & Disagree (KS) & 3 \\
4. & Less agree (TS) & 2 \\
5. & Strongly disagree (STS) & 1 \\
\hline
\end{tabular}
(Source : Sugiyono, 2016). 
JOSAR, Vol. 1 No. 2 September, 2018; p-ISSN: 2502-8251; e-ISSN: 2503-1155

Copyrights@ Balitar Islamic University, Blitar-Indonesia https://ejournal.unisbablitar.ac.id/index.php/josar

Next to determine the criteria score can be calculated using the following formula.

SK $=$ n.p.r

Description: $\mathrm{SK}=$ criteria score

$\mathrm{n}=$ highest score

$\mathrm{p}=$ number of question items

$r \quad=$ number of questions

The formula used to find out the validator percentage and readability test is as follows.

$\mathrm{P}=\frac{\sum x}{\sum X I} x 100 \%$

Description: $\quad P=$ percentage sought

$\Sigma \mathrm{x}=$ the number of respondents' answers

$\sum \times 1=$ number of ideal values

Table 2 Validity Level Criteria.

\begin{tabular}{ll}
\hline Percentage & denomination \\
\hline $0 \%-19 \%$ & Very unworthily \\
$20 \%-39 \%$ & Not feasible \\
$40 \%-59 \%$ & Quite decent \\
$60 \%-79 \%$ & Worthy \\
$80 \%-100 \%$ & Very decent \\
\hline
\end{tabular}
(Source : adapted from Sugiyono, 2011).

Product development that has been tested is evaluated to improve and refine local wisdom-based booklet teaching materials in Maliran forest, so that the products that have been developed are worthy of being used as teaching materials in schools on biodiversity material.

\section{RESULTS AND DISCUSSION}

The procedure for developing local wisdom based booklet teaching materials in the Maliran forest begins with the define stage used to conduct front end analysis, student analysis, task analysis, and concept 
JOSAR, Vol. 1 No. 2 September, 2018; p-ISSN: 2502-8251; e-ISSN: 2503-1155

Copyrights@ Balitar Islamic University, Blitar-Indonesia https://ejournal.unisbablitar.ac.id/index.php/josar

analysis. And The front analysis is used to identify and establish the basic problems needed in developing teaching materials. Teaching materials used in the form of LKS and text books lent by the school library. The results of student analysis show that students have different characteristics in learning. Concept analysis is to identify the main parts that will be taught systematically the concepts of biodiversity material. Analysis of tasks carried out in learning in accordance with $\mathrm{KI}$ and $\mathrm{KD}$ concerning biodiversity material.

The design phase is used to design booklet teaching materials that will be used in the learning process. The product design phase includes gathering sources or references used to compile booklet teaching materials, and collecting plant images from research results in the Maliran forest. The design of the teaching material of this booklet is made in full color to make it more attractive. The colors used adjust to the material and layout.

The develop phase is a product development stage developed based on suggestions and input from a team of experts including material experts, media experts, and language expert.

\section{a. Material expert}

The results of the complete material assessment can be seen in Table 3. The assessment of local wisdom-based booklet teaching materials in the Maliran forest by material experts was carried out in two stages. Based on the assessment of material experts in stage 1, it can be seen that the researcher gets a percentage of $70 \%$. This is because in the 4th statement the researchers got the lowest score, because the material contained in the booklet teaching material had not been presented in full, so researchers were advised to revise and evaluate the booklet teaching material in stage 2. In the stage 2 assessment the booklet-based teaching material product Local wisdom in the Maliran forest is declared feasible to 
JOSAR, Vol. 1 No. 2 September, 2018; p-ISSN: 2502-8251; e-ISSN: 2503-1155

Copyrights@ Balitar Islamic University, Blitar-Indonesia https://ejournal.unisbablitar.ac.id/index.php/josar

use with a score of $75 \%$. The score is proven by an increase in the acquisition score in the 4th statement, namely 12 with the statement that the booklet teaching material has fulfilled the completeness aspects of the material content.

Table 3 Tabulation of Material Assessment

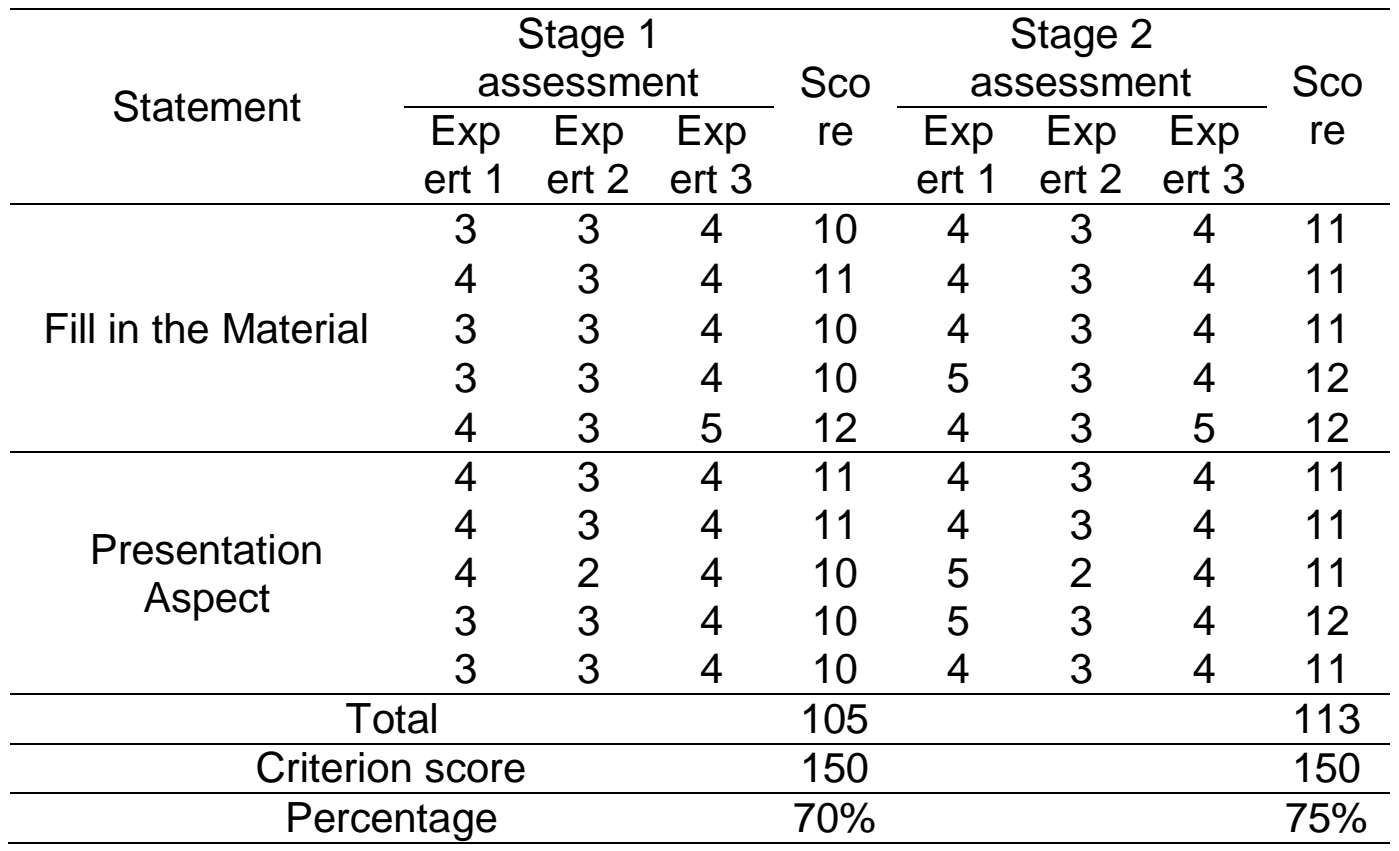

\section{b. Media expert}

The development of local wisdom based booklet teaching material products in the Maliran forest was validated by media experts. The assessment by media experts is carried out in 2 stages, because at stage 1 the researcher still gets a low score on a particular statement, so the validator suggests making improvements and then doing the stage 2 assessment. The results of the evaluation by the media experts can be seen in Table 4.

The results of the assessment of media experts in phase 1 of the researchers received a percentage of $71 \%$. This is because the aspect of color selection gets the lowest score, because the selection of colors in composing the booklet teaching material has not contrasted between the 
JOSAR, Vol. 1 No. 2 September, 2018; p-ISSN: 2502-8251; e-ISSN: 2503-1155

Copyrights@ Balitar Islamic University, Blitar-Indonesia https://ejournal.unisbablitar.ac.id/index.php/josar

background with writing or drawing. Furthermore, in the physical condition aspect, the researcher obtained a high score. so that researchers are advised to revise and assess the booklet teaching material in stage 2 . In the research phase 2, local wisdom-based booklet teaching products in the Maliran forest were declared suitable for use with an $80 \%$ score. The following is a tabulation table for assessment of booklet teaching materials by media experts.

Table 4 Tabulation of Evaluation of Media Experts

\begin{tabular}{|c|c|c|c|c|c|c|c|c|}
\hline \multirow{2}{*}{ Statement } & \multicolumn{3}{|c|}{$\begin{array}{c}\text { Stage } 1 \\
\text { assessment }\end{array}$} & \multirow{2}{*}{$\begin{array}{l}\text { Sco } \\
\text { re }\end{array}$} & \multicolumn{3}{|c|}{$\begin{array}{c}\text { Stage } 1 \\
\text { assessment }\end{array}$} & \multirow{2}{*}{$\begin{array}{l}\text { Sco } \\
\text { re }\end{array}$} \\
\hline & $\begin{array}{l}\exp \\
\text { ert } 1\end{array}$ & $\begin{array}{l}\exp \\
\text { ert } 2\end{array}$ & $\begin{array}{l}\exp \\
\text { ert } 3\end{array}$ & & $\begin{array}{l}\exp \\
\text { ert } 1\end{array}$ & $\begin{array}{l}\exp \\
\text { ert } 2\end{array}$ & $\begin{array}{l}\exp \\
\text { ert } 3\end{array}$ & \\
\hline \multirow{4}{*}{$\begin{array}{l}\text { Physical condition } \\
\text { of the book }\end{array}$} & 3 & 4 & 3 & 10 & 5 & 4 & 3 & 12 \\
\hline & 3 & 4 & 3 & 10 & 5 & 4 & 3 & 12 \\
\hline & 5 & 4 & 4 & 13 & 5 & 4 & 4 & 13 \\
\hline & 3 & 3 & 4 & 10 & 5 & 3 & 4 & 12 \\
\hline \multirow{3}{*}{ Letters used } & 3 & 4 & 3 & 10 & 5 & 4 & 3 & 12 \\
\hline & 3 & 3 & 3 & 9 & 5 & 3 & 3 & 11 \\
\hline & 2 & 3 & 4 & 9 & 5 & 3 & 4 & 12 \\
\hline Clarity of selection & 5 & 4 & 3 & 12 & 5 & 4 & 3 & 12 \\
\hline \multirow[t]{2}{*}{ an image layout } & 4 & 4 & 4 & 12 & 5 & 4 & 4 & 13 \\
\hline & 3 & 3 & 4 & 10 & 4 & 3 & 4 & 11 \\
\hline \multirow{4}{*}{ Color selection } & 2 & 3 & 3 & 8 & 5 & 3 & 3 & 11 \\
\hline & 2 & 3 & 3 & 8 & 5 & 3 & 3 & 11 \\
\hline & 3 & 4 & 3 & 10 & 5 & 4 & 3 & 12 \\
\hline & 3 & 4 & 4 & 11 & 5 & 4 & 4 & 13 \\
\hline \multirow{5}{*}{$\begin{array}{l}\text { Compilation of } \\
\text { content sections }\end{array}$} & 5 & 4 & 4 & 13 & 5 & 4 & 4 & 13 \\
\hline & 5 & 4 & 3 & 12 & 5 & 4 & 3 & 12 \\
\hline & 5 & 4 & 3 & 12 & 5 & 4 & 3 & 12 \\
\hline & 4 & 4 & 4 & 12 & 5 & 4 & 4 & 13 \\
\hline & & & & 191 & & & & 217 \\
\hline \multicolumn{4}{|c|}{ Criterion score } & 270 & & & & 270 \\
\hline \multicolumn{4}{|c|}{ Percentage } & $71 \%$ & & & & $80 \%$ \\
\hline
\end{tabular}

\section{c. Language Expert}

The results of the assessment of local wisdom-based booklet teaching materials in the Maliran forest by linguists, researchers obtained an assessment score of $76 \%$. The score is included in the assessment 
JOSAR, Vol. 1 No. 2 September, 2018; p-ISSN: 2502-8251; e-ISSN: 2503-1155

Copyrights@ Balitar Islamic University, Blitar-Indonesia https://ejournal.unisbablitar.ac.id/index.php/josar

range of $60 \%-79 \%$ and is included in the feasible category. The results of the assessment of local wisdom based booklet teaching materials on communicative, straightforward, and motivational aspects obtained high scores, while in the aspect of conformity with Indonesian language rules, researchers obtained a low score. This is because the use of spelling in booklet teaching materials is not in accordance with EYD. Assessment of linguist validation is only done once, this is because the validator states that based on linguistic aspects used in the booklet teaching materials are in accordance with predetermined criteria. Tabulation of assessment of booklet teaching materials can be seen in Table 5 .

Table 5 Tabulation of Language Expert Assessment

\begin{tabular}{ccccc}
\hline \multirow{2}{*}{ Assessment } & \multicolumn{5}{c}{ Scoring scale } \\
& Expert & Expert & Expert & Score \\
& 1 & 2 & 3 & \\
\hline \multirow{2}{*}{ Straightforward } & 4 & 4 & 4 & 12 \\
& 4 & 4 & 3 & 11 \\
\hline Communicative & 4 & 4 & 3 & 11 \\
\hline Motivational ability & 4 & 4 & 4 & 12 \\
\hline $\begin{array}{c}\text { Conformity with Indonesian } \\
\text { Language rules }\end{array}$ & 4 & 4 & 4 & 12 \\
\hline Criterion score & 3 & 4 & 3 & 10 \\
\hline Percentage & & & 68 \\
\hline
\end{tabular}

\section{d. Readability Test}

The readability test results were carried out by 5 XI MIA students who had taken biodiversity material. the score for the readability test is listed in Table 6.

Table 6 Tabulation of Readability Tests

\begin{tabular}{|c|c|c|c|c|c|c|}
\hline \multirow[b]{2}{*}{ Assessment } & \multicolumn{5}{|c|}{ judgment } & \multirow[b]{2}{*}{$\begin{array}{c}\text { Scor } \\
\mathrm{e}\end{array}$} \\
\hline & $\begin{array}{l}\text { Stude } \\
\text { nt } 1\end{array}$ & $\begin{array}{c}\text { Stude } \\
\text { nt } 2\end{array}$ & $\begin{array}{c}\text { Stude } \\
\text { nt } 3\end{array}$ & $\begin{array}{c}\text { Stude } \\
\text { nt } 4\end{array}$ & $\begin{array}{c}\text { Stude } \\
\text { nt } 5\end{array}$ & \\
\hline \multirow{2}{*}{ Material Coverage } & 4 & 4 & 4 & 4 & 4 & 20 \\
\hline & 4 & 4 & 3 & 4 & 4 & 19 \\
\hline
\end{tabular}


JOSAR, Vol. 1 No. 2 September, 2018; p-ISSN: 2502-8251; e-ISSN: 2503-1155

Copyrights@ Balitar Islamic University, Blitar-Indonesia https://ejournal.unisbablitar.ac.id/index.php/josar

\begin{tabular}{ccccccc} 
& 4 & 4 & 4 & 4 & 4 & 20 \\
& 4 & 5 & 3 & 4 & 4 & 20 \\
\hline \multirow{5}{*}{ Graphic Design } & 4 & 5 & 3 & 3 & 4 & 19 \\
& 4 & 4 & 2 & 4 & 4 & 18 \\
& 4 & 4 & 4 & 5 & 4 & 21 \\
& 4 & 4 & 3 & 3 & 4 & 18 \\
& 4 & 4 & 4 & 4 & 4 & 20 \\
Language & 4 & 5 & 3 & 4 & 5 & 21 \\
& 4 & 4 & 3 & 4 & 5 & 20 \\
\hline Total & 4 & 4 & 4 & 4 & 4 & 20 \\
& 4 & 4 & 4 & 4 & 4 & 20 \\
& 4 & 4 & 4 & 3 & 3 & 18 \\
\hline & 56 & 59 & 48 & 54 & 57 & 274 \\
\hline & Criterion score & & & 350 \\
\hline & Percentage & & & $78 \%$ \\
\hline
\end{tabular}

The results of the assessment of readability tests on local wisdombased booklet teaching materials in the Maliran forest conducted by 5 students of class XI MIA scored $78 \%$. This score is included in the assessment range of $60 \%-79 \%$ and is included in the feasible category.

Based on expert validation assessment and readability test shows that local wisdom based booklet teaching materials in Maliran forest are worthy of being used as teaching materials in biodiversity material. Scoring scores by material experts, media experts, and linguists respectively were $72.5 \%, 77.5 \%, 76 \%$ with an average assessment by expert teams of $75.3 \%$ with a decent category. Readability test results get an assessment score of $78 \%$ with a decent category. The results of the validation are similar to the research conducted by Susilawati (2015) which stated that the booklet was declared valid to be used as a learning media in the biodiversity submersion. The same was stated by Holilah et al. (2018) which stated that the booklet was declared valid and feasible to be used in learning on class $\mathrm{X}$ Indonesian biodiversity material.

Development of booklet teaching materials get input and suggestions from examiners. The input and suggestion is one part of product 
JOSAR, Vol. 1 No. 2 September, 2018; p-ISSN: 2502-8251; e-ISSN: 2503-1155

Copyrights@ Balitar Islamic University, Blitar-Indonesia https://ejournal.unisbablitar.ac.id/index.php/josar

evaluation, so that later the booklet teaching material products that have been developed are suitable for use in learning activities. Inputs and suggestions from the examiners include the need for improvements in page settings so that the booklet developed is not too thick. On the diversity of plant species adapted to the material or level of biodiversity. Furthermore, in the one activity section on the level of biodiversity, it should be placed after the material diversity of the ecosystem level, so that the arrangement of material with tasks or exercises can be arranged with a clear concept. Based on these suggestions and input, product improvements can then be made, so that the products that have been developed are suitable for use in learning activities and researchers can use these products on a wider scale.

\section{CONCLUSION}

Local wisdom based booklet teaching materials in Maliran forest received an assessment by material experts $72.5 \%, 77.5 \%$ media experts, and $76 \%$ linguists. Based on the expert assessment scores obtained an average score of $75.3 \%$, the value is included in the feasible category. Readability test obtained a percentage of $78 \%$, including the feasible category. Based on the results of data analysis that has been obtained, it can be concluded that the local wisdom-based booklet teaching material in Maliran forest can be declared suitable for use as teaching material in class $\mathrm{X}$ biodiversity material. 
JOSAR, Vol. 1 No. 2 September, 2018; p-ISSN: 2502-8251; e-ISSN: 2503-1155

Copyrights@ Balitar Islamic University, Blitar-Indonesia https://ejournal.unisbablitar.ac.id/index.php/josar

\section{SUGGESTION}

Based on the conclusions above, the researcher gave suggestions for the development of local wisdom-based booklet teaching materials, among others, as follows.

1. The development of booklet teaching materials conducted by researchers is limited to the develop stage, so it is recommended that further research be carried out until the disseminate stage.

2. Development of local wisdom-based booklet teaching materials that discuss plant diversity in the Maliran forest, further research is needed to discuss other biodiversity, so that booklet teaching materials can become innovations in the world of education.

3. The development of booklet teaching materials in this study is printed teaching materials, therefore the researchers suggest for further research to make booklet teaching materials into digitalbased teaching materials and can be accessed online.

\section{REFERENCES}

Holilah S, Entin D, Titin. 2018. Feasibility of booklets on biodiversity material based on morphology and nutrient content of tepo, kereke, and pyrite fruits. Journal of Education and Learning.7 (7): 1-9.

Imtihana M, Putut M, H.B, Bambang P. 2014. Development of ResearchBased Booklets as Learning Resources for Circle Pollution Materials in High Schools. Essay. Biology Department, FMIPA Semarang State University, Indonesia. Semarang.

Indasari H. 2016. Development of Phylum Echinodermata Bio-Booklet as Independent Learning Resources for Class X High School / MA Students. Essay. Faculty of Science and Technology at Sunan Kalijaga UIN Yogyakarta.

Mannan MN, Sopyan A, Sunarno. 2015. Development of Local Wisdom Based Learning Devices to Develop Positive Character of Elementary Students. Journal of Physics Innovation and Learning. 2 (2): 141-146. 
JOSAR, Vol. 1 No. 2 September, 2018; p-ISSN: 2502-8251; e-ISSN: 2503-1155

Copyrights@ Balitar Islamic University, Blitar-Indonesia

https://ejournal.unisbablitar.ac.id/index.php/josar

Prastowo A. 2015. Creative Guide to Making Innovative Learning Materials. Yogyakarta: DIVA Press.

Sugiyono.2011. Quantitative, Qualitative, and $R$ \& $D$ Research Methods. Bandung: Alfabeta.

Sugiyono.2016. Quantitative, Qualitative, and $R$ \& D Research Methods. Bandung: Alfabeta.

Susilawati N, Syamswisna, Reni M. 2015. The feasibility of the media in the etbotani booklet in the village of heavy currents in the submission of benefits of high school biodiversity. Education Journal. 1 (3): 3-15. 